\title{
Implementation of offshore reclamation methods on an old tin mining area on Bangka Island, Indonesia
}

\author{
IA Syari University of Bangka Belitung, Indonesia \\ J Sudrajat Ministry of Energy and Mineral Resources, Indonesia \\ HA Octaviano Ministry of Energy and Mineral Resources, Indonesia \\ B Hutahaean PT TIMAH Tbk, Indonesia
}

R Adnis PT TIMAH Tbk, Indonesia

OA Taruk Allo PT TIMAH Tbk, Indonesia

\begin{abstract}
The high demand for tin as a raw material requires tin producers to generate large quantities for use in various products. Several companies, both state-owned and private, are vying to increase production through the exploration and exploitation of tin resources on land and water. Mining activities on the Bangka Belitung Islands, especially offshore mining activities, have a positive economic impact for the local community. However, these activities have had negative effects, too, such as the environmental degradation of marine ecosystems - when, for instance, the mining activities have not been conducted according to the principles of mining environmentally and sustainably. Thus, extensive mining has caused changes, such as damage to mangrove forests and an increasing amount of fine sediment and suspended soil at the bottom of the sea. Mangrove damage will make the islands more vulnerable to the sea water, while the addition of fine sediment to the sea will increase turbidity and reduce the amount of light available for photosynthesis, creating a hostile environment for coral and fish and thus reducing their populations. PT TIMAH Tbk is one of the state-owned companies engaged in tin mining; it has permission to mine in the sea with as many as 27 permits or an area of 184,672 hectares. PT TIMAH Tbk has conducted offshore reclamation (rehabilitation) as one of its obligations as a mining company. This has included planting mangroves (35,000 stems), providing fish shelters and transplanting coral (861 units). The results of the mangrove planting cannot yet be determined due to the short observation period. However, the coral transplantations and fish shelters are showing better results because these two programs are creating promising artificial habitats for coral and fish.
\end{abstract}

Keywords: offshore reclamation; PT TIMAH Tbk; responsible mining; mine closure; mangrove planting, fish shelter and coral transplantation; Bangka Belitung Indonesia

\section{Introduction}

Tin is a mineral resource used in many products. In Indonesia, tin ore can be mined on land or offshore. PT TIMAH Tbk is a large-scale mining company in Indonesia that focuses on tin mining at Bangka Belitung Islands. Offshore mining plays an important role in tin production, contributing $61.15 \%$ of its total production (Saragih 2018). Nevertheless, offshore mining also creates environmental problems that should be addressed. Dredging activities to obtain tin also remove coral reef, influence the benthic ecosystems through physical changes, reduce the level of oxygen by increasing debris and turbidity, and reduce the amount of available light to corals and sea creatures (Bak 1978; Charlier 2002; Jaap 2000). Therefore, sea restoration, otherwise known as 'sea reclamation', is needed to improve the condition of the sea after the mining activities are completed. 
The purpose of sea reclamation is to normalise the coral reef and return fish and their habitat to the former mining area. Several factors need to be considered before sea reclamation can begin. First, before the mining activity commences, mining companies should conduct an environmental impact assessment, which is defined by the International Association for Impact Assessment as 'the process of identifying, predicting, evaluating and mitigating the biophysical, social and other relevant effects of development proposals prior to major decisions being taken and commitments made' (Senecal et al. 1999). Conducting an environmental impact assessment ensures that there will be information regarding the initial condition before the area is mined and that efforts will be made to reduce environmental problems during the activity and return the condition of the sea to its pre-mining condition or better. Ellis et al. (2017) describe the potential impacts that should be analysed in an environmental impact assessment for tin mining, such as loss of habitat for fish and invertebrates, establishment of a hostile environment for benthic organisms due to an increase in silt or clay materials, discharge of potential toxic or harmful substances from machinery or mineral extraction in the seabed, increasing levels of sediments suspended in the seabed, and changing hydrologic conditions that can adversely impact the surrounding areas. Second, monitoring is required during the mining activities to avoid the aforementioned adverse impacts. Third, sea reclamation should be undertaken after the mining activity has finished.

According to Energy and Mineral Resources Ministerial Decree Number 1827 K/30/MEM/2018 concerning the Guidelines for the Implementation of Good Mining Engineering Rules, 'reclamation' is defined as activities conducted throughout the mining stages to organise, restore and improve the quality of the environment and ecosystem so that they can function again according to their designation. Land and sea reclamation have several differences, mainly in the form of the final designation. Land reclamation can be done in several ways, such as turning the land back into forest (Zipper et al. 2011), grazing or agricultural areas (Limpitlaw \& Briel 2014; Wang et al. 2017) a water reservoir (Soni et al. 2014) and a tourism site (Barbosa et al. 2019). However, the sole purpose of sea reclamation is to normalise the sea environment. Therefore, sea reclamation can be achieved in several ways, such as establishing a mangrove plantation, creating fish shelters and transplanting coral. In this paper, we provide information on sea reclamation with a focus on these three activities.

Indonesia is an archipelago country consisting of many small islands. The coasts of these small islands are vulnerable to erosion caused by long-term sea level rise, global warming and tidal fluctuations (Ellison 1993; Gilman et al. 2006). Tin mining is also responsible for the increasing threat to the island posed by waves or tidal fluctuations, which can threaten human life. Several examples of how tin mining can damage mangrove forests can be seen in Thailand (Chansang 1988) and on Bangka Island (Siburian \& Haba 2016). Mangroves are important not only as a barrier to the waves but also for the livelihood of the local people. Many mangrove forests on Bangka Island provide food, such as crabs and fish (Siburian \& Haba 2016). Moreover, mangrove forests can become home to local birds and fish and can reduce flood levels (Adger et al. 1997).

Therefore, in order to rehabilitate the conditions, returning the mangroves to the island is important. However, planting mangroves differs from planting trees on dry land and requires specific methods. The condition of the area will also affect the mangrove species selection. For example, with a project in Bangladesh, only two of the 27 mangrove species have survived (Saenger \& Siddiqi 1993). Furthermore, the soil conditions, such as soil salinity and pH, greatly influence the selection of the species (Shiau et al. 2017; Wakushima et al. 1994).

Tin mining in the sea also influences the number of fish and corals by changing the marine environment. Usually, tin mining activity on Bangka Island uses dredging tools or a suction pontoon. Both methods damage the creatures that inhabit the bottom of the sea, such as fish and corals. The coral damage in several areas around Bangka Island has already reached an alarming level. Moreover, the coral cover in those areas is at the stage of moderate damage, which means the average coral cover in those areas is 
40-50\% (Adibrata 2013; Siringoringo \& Hadi 2013). Several factors contribute to the decreasing numbers of corals and fish, and one of those factors is tin mining activity (Nurtjahya et al. 2017; Siburian \& Haba 2016).

Coral reefs are important ecosystems in the sea. Damage to the coral will reduce the number of fish because their playground and the area to search for food have been changed. Moreover, coral reefs are valuable not only as habitats for fish but also as coastal protection and as a source of tourism (Chabanet et al. 2005; Clark \& Edwards 1999). In order to re-establish the number of fish, it is important to restore the habitats for the fish and the coral. Creating a fish shelter is one way to increase the number of fish residing in a certain area. An experiment in which the amount of shelter available for salmon was manipulated had a direct influence on the salmon's growth and mortality rate (Finstad et al. 2007). Hence, shelter manipulation will also attract other fish. Shelter also provides protection from predators (Steele 1999). Thus, more fish will come to seek refuge.

Coral reefs can be restored in two ways: natural recovery and human-induced recovery. Natural recovery of coral can take more than 10 years because growth is very slow for heavily damaged areas (Bowden-Kerby 2003; Jaap 2000). The process of restoring coral reefs can be accelerated through human involvement via coral transplantation. Bowden-Kerby (2003) describes a successful coral transplantation in Fiji and the Solomon Islands after the coral reefs were damaged by overfishing and severe storms. He divides the transplantation into three areas: an area with shallow water consisting of high energy (lots of waves and sediment movement); lagoon areas dominated by rubble from a severe storm, blasting and coral mining; and a sandy area. For the severely damaged area, Bowden-Kerby and the Fijian community used igloo-shaped fish houses made of cement and stone, which they cemented onto the reef flat to protect the reef from high temperatures, water turbulence and algae. On the Pacific coast of Costa Rica, an experiment with coral fragmentation conducted by Guzmán (1991), which had a success rate of 79-83\%, involved low-tech transplantation of local dominant coral (Pocillopora spp.) in shallow water. Other successful experiments with coral transplantation have occurred in Taiwan (Soong \& Chen 2003) and the Philippines (Shaish et al. 2008).

PT TIMAH Tbk has conducted several programs to improve the condition of the environment damaged by mining activities, especially in coastal areas and the sea. Those programs have included planting 35,000 stems of mangroves, installing fish shelters and transplanting 861 units of coral. With our study, we aimed to answer two main questions regarding these programs: (1) What is the survival rate of the mangrove plantation planted under PT TIMAH Tbk's program given that mangroves are very sensitive to soil conditions, and (2) What is the effect of fish shelter installation and coral transplantation in areas affected by tin mine activities, and can these methods create a new habitat for sea creatures? Our study shows that the effort required to create an artificial habitat is worthwhile with both projects showing promising progress: the corals are surviving well and there are signs of fish playing in the fish shelter. Thus, these programs can be used as an example for other areas affected by mining activities.

\section{Methodology}

\subsection{Study areas and time}

Data collection was conducted on Bangka Island and divided into two observations-namely, fish shelter observation and coral transplantation observation. The fish shelter observations were conducted at Panjang Island and Matras waters. The coral transplant observations were conducted at Panjang Island and Putri Island, on behalf of PT TIMAH Tbk. The location and distribution of the fish shelters and coral transplantations were determined based on the environmental impact assessment. It was also essential that no mining activities would occur in each location and that each location was approved by the Ministry of Energy and Mineral Resources as stated in the Document of Reclamation Plan. Broadly, the three locations were in the eastern waters of Bangka Island (Figure 1). 


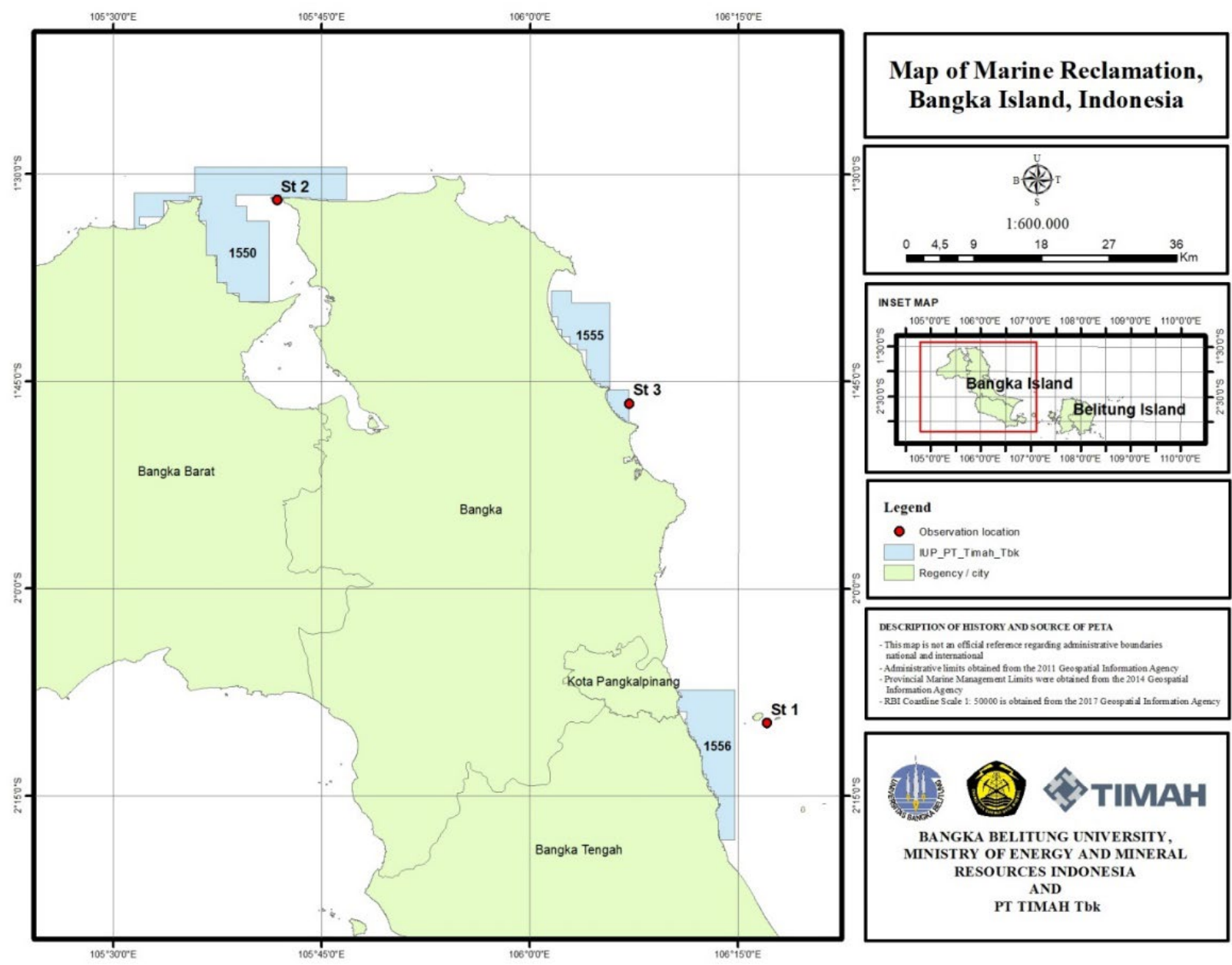

Figure 1 Observation location map (St 1 = Panjang Island, St 2 = Putri Island, and St $3=$ Matras waters)

Based on observations of their initial condition, it is clear that the coral reefs in the western, eastern and southern parts of Bangka Island have been damaged, and the damaged area is about seven kilometres from the coast. Only the northern part is in good condition. The damage to the coral reef is being caused by floating-boat mining activities, which are quite large in number and have continued for a long time. Additionally, there are signs of unfriendly activities, disease, predators and nearby port activities, where the source is unknown due to limited data for the area. The sinking of the coral transplantation and fish shelter modules was conducted in the northern area of Panjang Island with consideration to minimise the impact of siltation due to mining activities. With Putri Island, the sinking of the coral transplantation module was conducted in the west-the area facing Bangka Island-because the condition of the coral reef is better in this area. However, the waters are shallower at Putri Island than at Panjang Island, with Putri Island being about two kilometres from the coast of Bangka Island. The depth at Putri Island after the slope is only about three to five metres, while at Panjang Island the depth is around six to eight metres. The sinking of fish shelters at Matras waters was carried out far from coral areas and beaches. The sinking point is located seven kilometres from the shoreline and at a depth of greater than 10 metres (the depth is measured based on the average tide). This was done in order to determine the correlation between fish abundance and the depth of the sea. 
The sinking and observations were carried out three times in three different locations. The time interval between the sinking and the observation of the fish shelter is five months. The time of the sinkings of the modules and the observations of the fish shelter and coral transplants for each location are presented in Table 1.

Table 1 Location, time and number of modules sunk and observed

\begin{tabular}{|c|c|c|c|c|c|c|c|}
\hline \multirow{2}{*}{ No } & \multirow{2}{*}{ Location } & \multicolumn{2}{|l|}{ Date } & \multicolumn{2}{|c|}{ Coordinate points } & \multirow{2}{*}{ Trans. } & \multirow{2}{*}{ FS } \\
\hline & & Sinking & Observation & $x$ & $\mathbf{Y}$ & & \\
\hline 1 & Panjang Island & 23-26 July 2018 & 2 December 2018 & 0642818 & 9760984 & 40 & 40 \\
\hline 2 & Putri Island & 06-11 June 2018 & 21 November 2018 & 0577450 & 9830826 & 100 & - \\
\hline 3 & Matras waters & 20 November 2017 & 2 June 2018 & 0624483 & 9803654 & - & 20 \\
\hline
\end{tabular}

Note: Trans. $=$ Number of coral transplantation modules, FS = Number of coral transplantation modules.

The area differs from the above for mangrove planting. Mangrove plantations occur on Kundur Island, as seen in Figure 2.

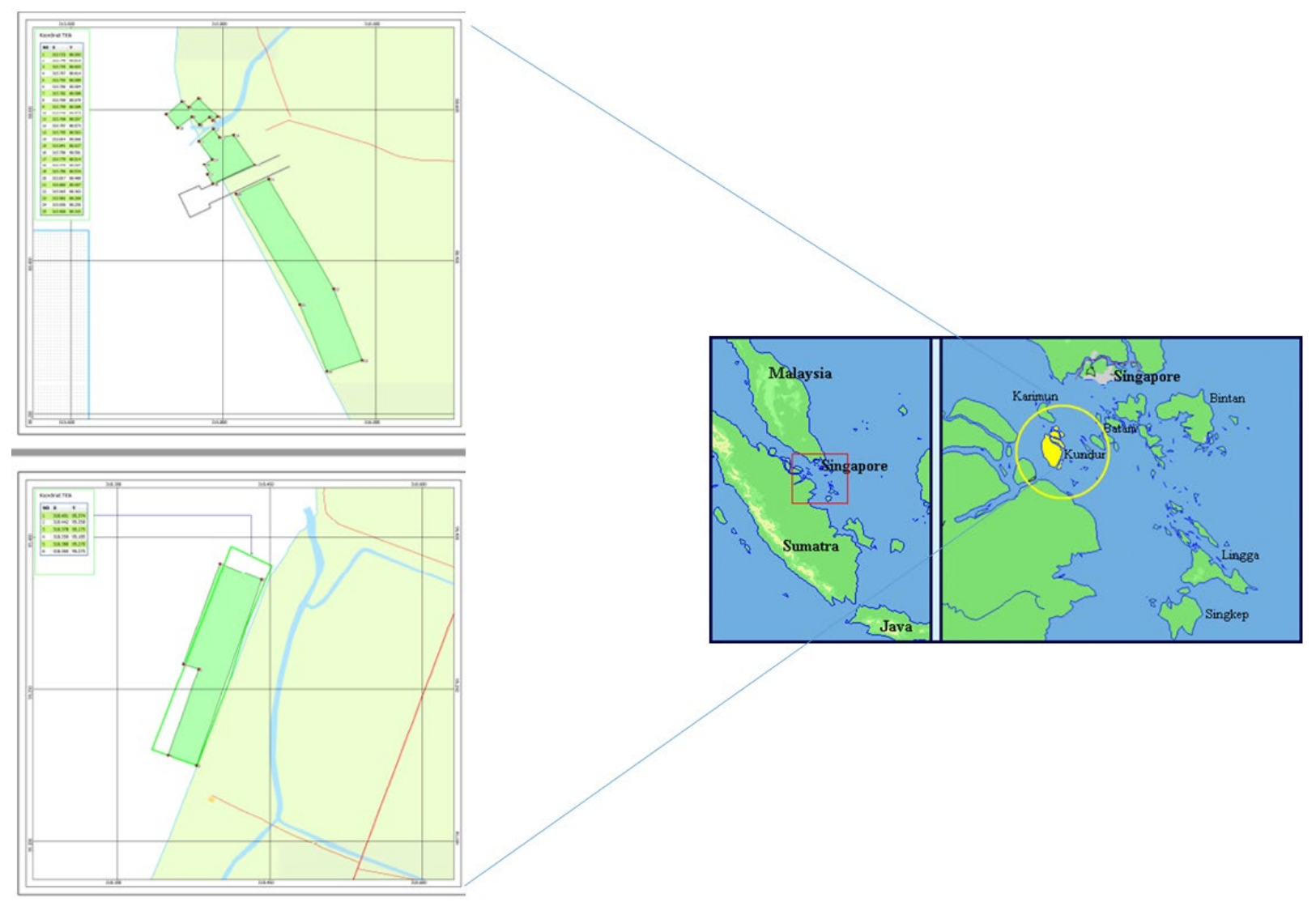

Figure 2 Map of Kundur Island and reclamation area

\subsection{Material}

The research material consists of multiple coral transplantation modules, each in the form of an iron frame measuring $1 \times 1 \times 1 \mathrm{~m}^{3}$ (Figure 3). The number of coral transplantation modules submerged was 40 units at Panjang Island and 100 units at Putri Island. Each coral transplantation module consists of 12 pieces of substrate media consisting of clay pottery. The transplant media (clay pottery) was chosen because it is inexpensive and abundant where it is locally produced. 


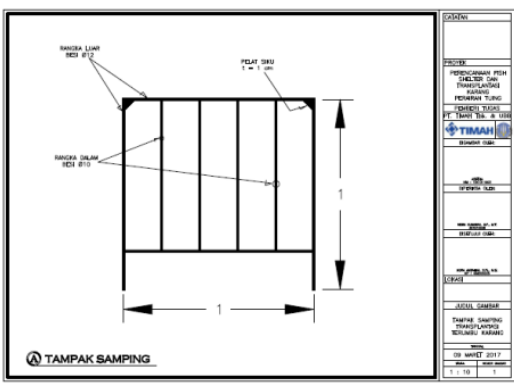

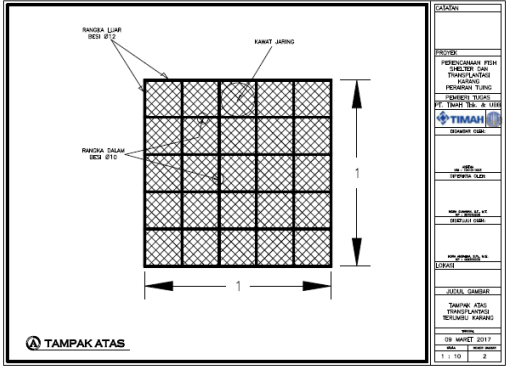

(a)

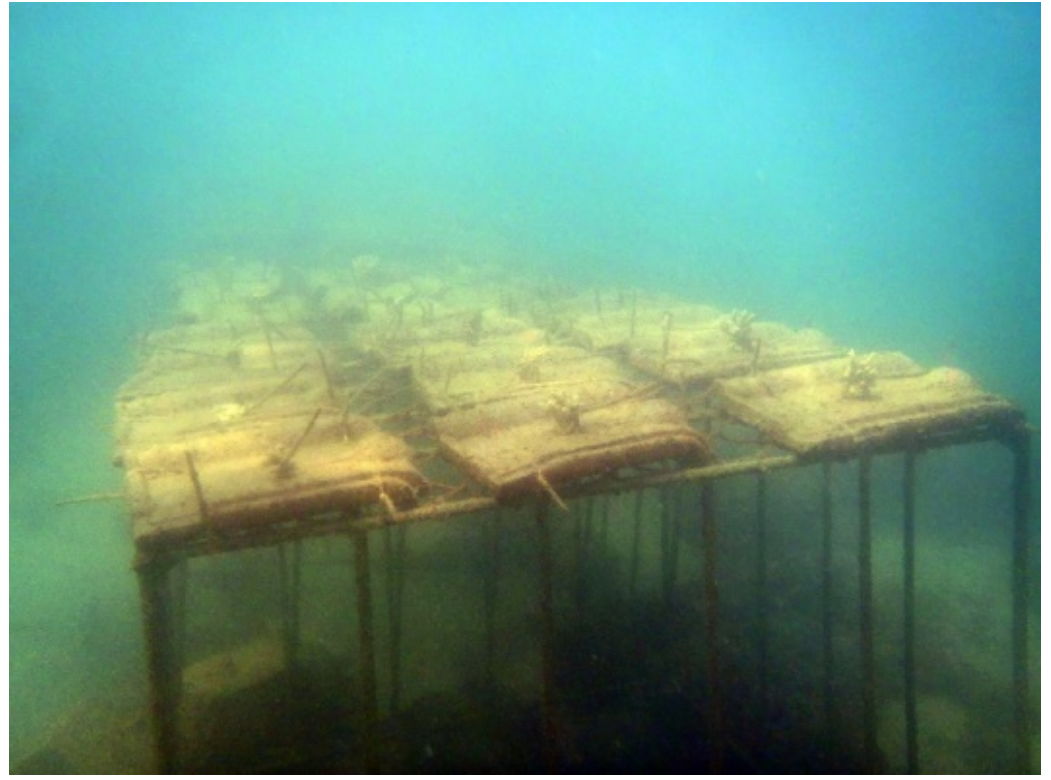

(b)

Figure 3 (a) Coral transplantation module design; (b) A coral transplantation module that was sunk

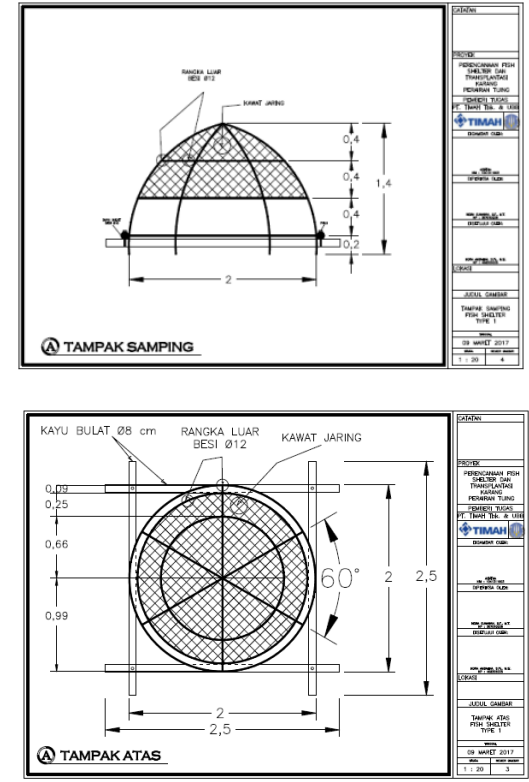

(a)

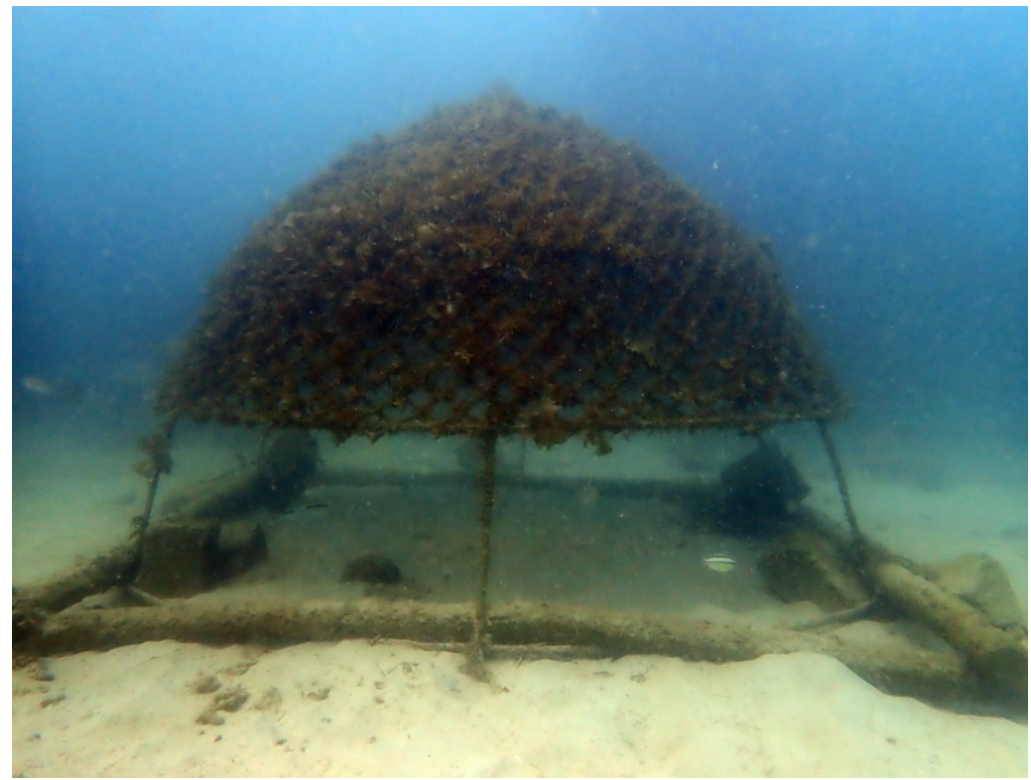

(b)

Figure 4 (a) Fish shelter module design; (b) A fish shelter module that was sunk

The fish shelter module is also in the form of an iron frame, in the shape of a semi-sphere with a dimension of $2 \times 2 \times 1.4 \mathrm{~m}^{3}$ (Figure 4). The design was selected because it is similar to the icon of the province of Bangka Belitung Islands and, as such, it has the potential to attract tourists when the areas are ready to be opened to the public. The form also has many holes to prevent sediment from covering the shelter, therefore creating enough light for the fish. Forty fish shelter modules were sunk at Panjang Island, and 60 were sunk in Matras waters. Each coral transplantation module and fish shelter module has eight ballast/sinker units to keep the module stable and to ensure that it is not easily overturned or washed away by currents or waves 
For mangroves, several plants have been tested for their suitability to the land. Several that have been planted in the area are species of the genera Rhizophora, Sonneratia and Avicennia (Figure 5).

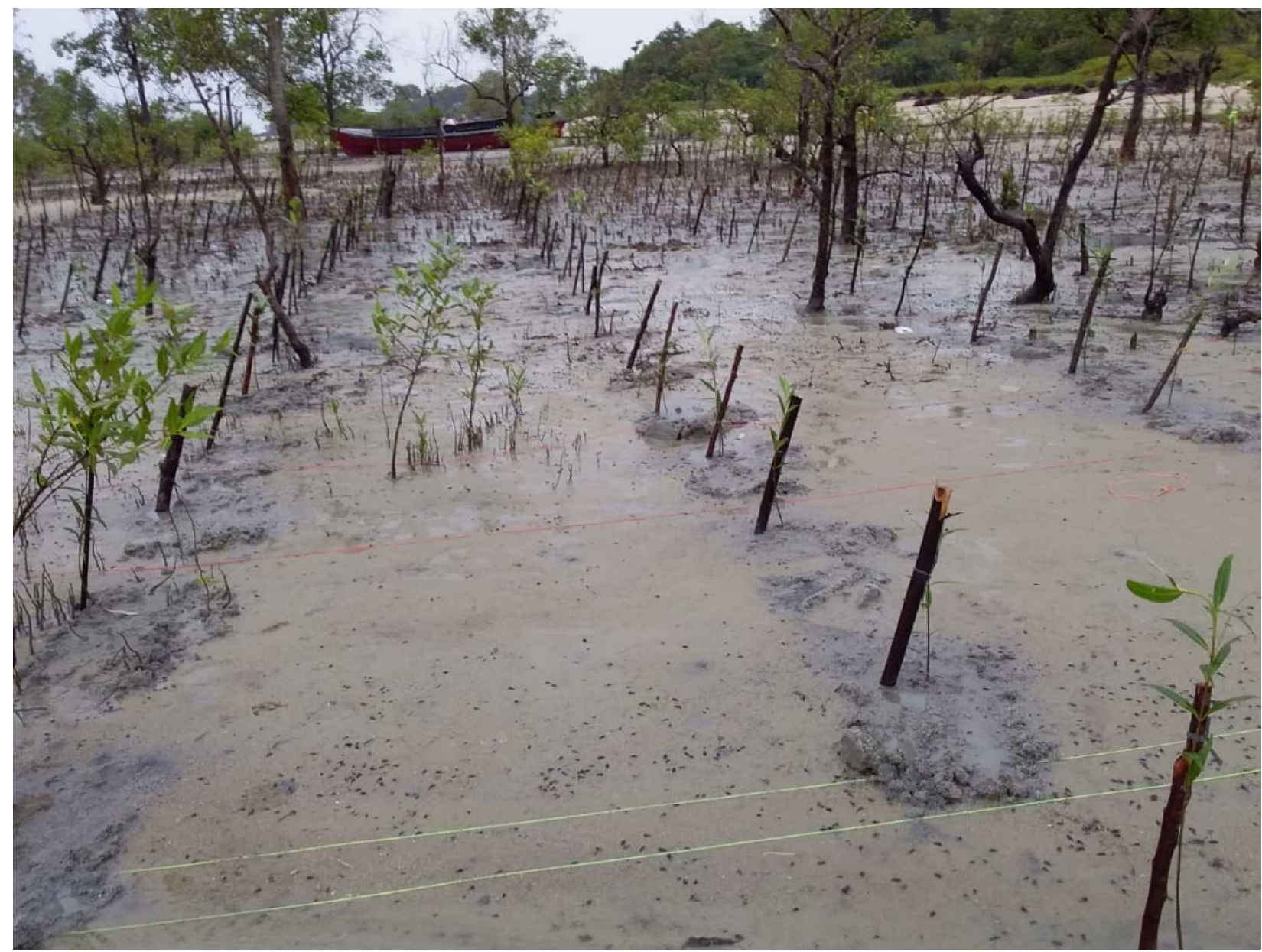

Figure 5 Mangrove plantation in the field

\subsection{Equipment}

The equipment used in the observations includes diving equipment, underwater cameras, fish identification books, underwater stationery, a GPS, boats, and a ruler or metre gauge.

\subsection{Sinking}

The sinking is carried out with the involvement of local people and fishermen; this empowers communities living around the mine (Figure 6). The fish shelter and coral transplantation modules were deliberately designed so that moving them from the coast to the sinking point could be carried out by local fishing boats. Sinking is carried out after all of the coral transplantation and fish shelter modules have been transported to the coast. Generally, the sinking process is carried out in stages:

- The preparation of the coral transplantation modules (binding between the framework with the media of pottery substrate) and fish shelter modules (making wooden bases and binding them with iron frames), which is carried out by local communities in locations not far from the sinking area.

- The transportation, by boat, of all equipment to the sinking location, which also involves the local community. 
- The sinking of all coral transplantation and fish shelter modules according to predetermined numbers and points.

- The arrangement of coral transplantation and fish shelter modules by divers from the University of Bangka Belitung team with assistance from the community and local fishermen supervised by a team from PT TIMAH Tbk. The position of the coral transplantation and fish shelter modules is parallel with coral reefs, at a distance of two to three metres from the last coral slope. The arrangement, if seen from the coral reef, is in the sequence of a coral transplantation module, followed by a semi-spherical fish shelter module.

- The installation of sinkers for each coral transplantation and fish shelter module. Each is installed with the same amount: eight ballast units. Previously, two ballast units had been used. It is hoped that with the increased ballast the coral transplantation and fish shelter modules will not move to other locations.

- The installation of transplant corals on the tile-based media in the coral transplantation modules.

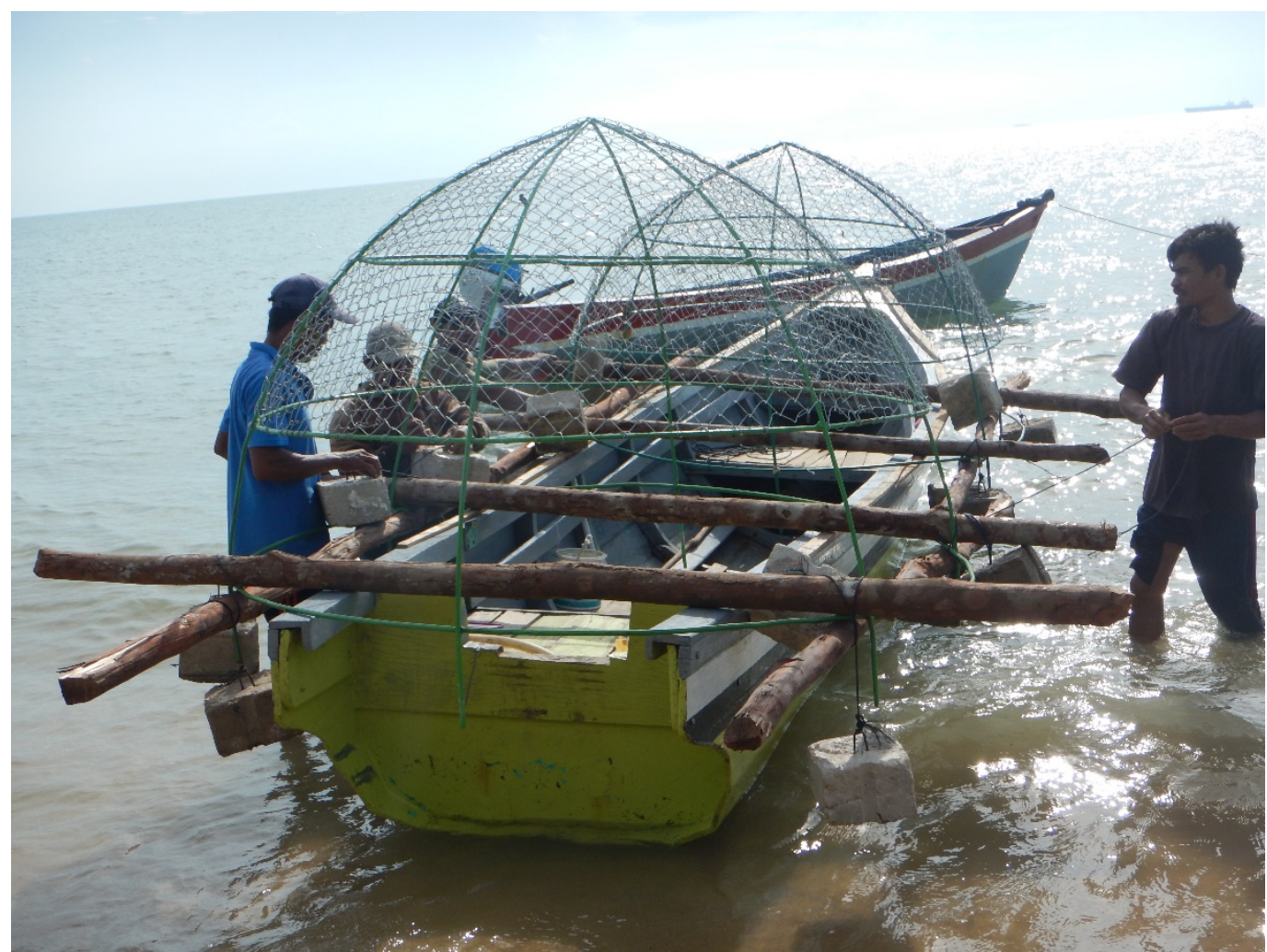

Figure 6 Fish shelter sinking by local fishermen

\subsection{Mangrove plantation}

An initial survey of a potential planting location is needed to determine whether it is appropriate to plant mangroves in that location. Mangrove planting can be done using one of two methods depending on conditions at the location:

- $2 \mathrm{~m} \times 1 \mathrm{~m}$ spacing method.

At the planting stage, mangroves are grouped by species. Mangrove seedlings are planted at the planting site with a spacing of $2 \mathrm{~m} \times 1 \mathrm{~m}$ by using the engraving method. Engraving is useful to keep mangrove seeds from falling when hit by waves. 
Mangroves are planted by making holes near the stand, with the circumference of each hole bigger than a polybag and the depth twice the length of a polybag. Seedlings are planted upright into the planting hole by releasing them from polybags carefully in order to avoid damaging the roots. The areas between the holes and around the seedlings are then filled with sediment. The trunks of the seedlings are tied to sticks, so that they are less likely to fall when there is a high tide. Figure 7 shows an example.

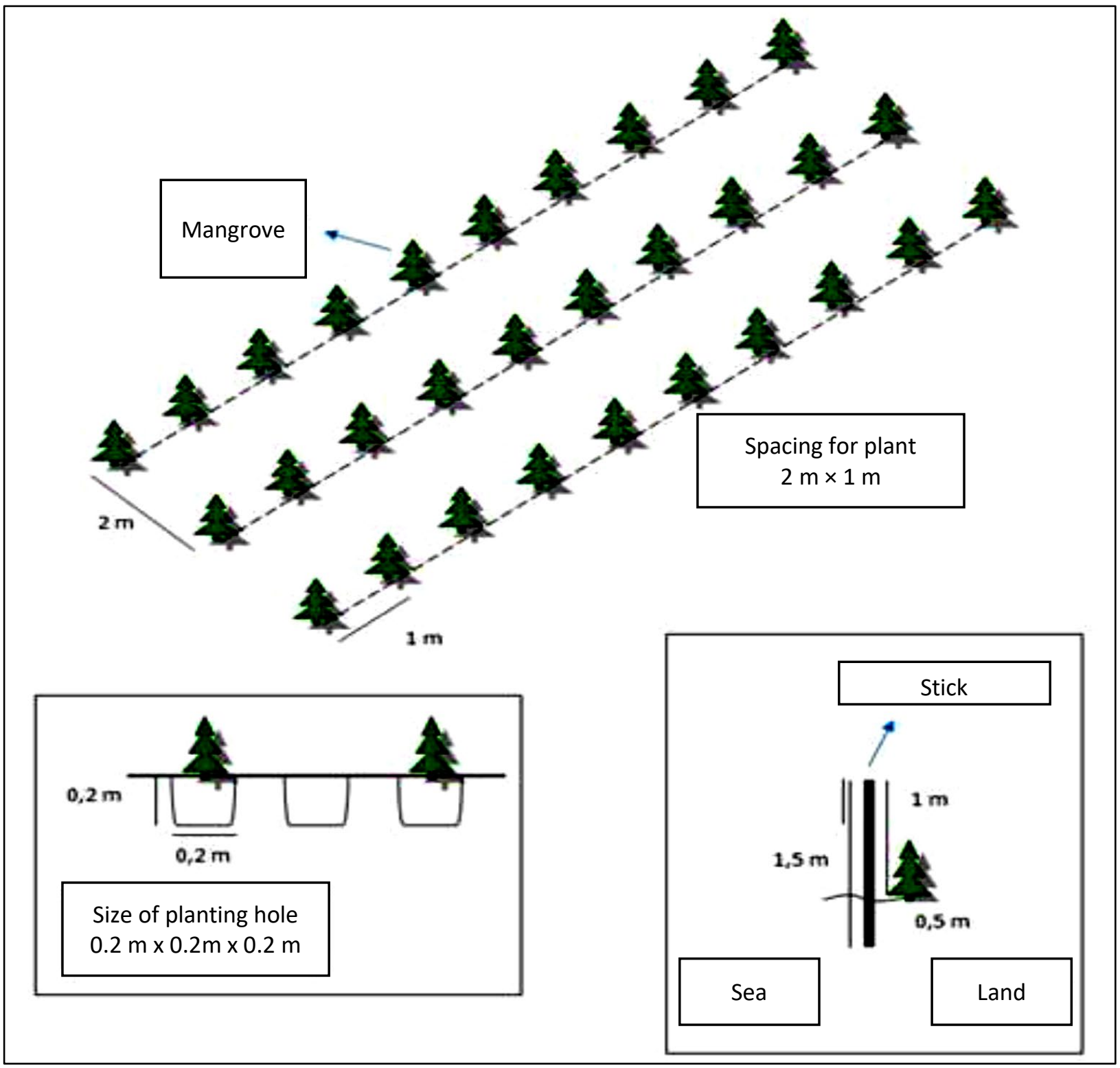

Figure 7 Spacing method of $2 \mathrm{~m} \times 1 \mathrm{~m}$

- Cluster method.

At the planting stage, mangroves are grouped by species. Mangrove seedlings are planted by using the cluster method, which provides empty space between the clusters. The use of engraving or the cluster method is useful to keep mangrove seedlings from falling when exposed to waves (Figure 8). 


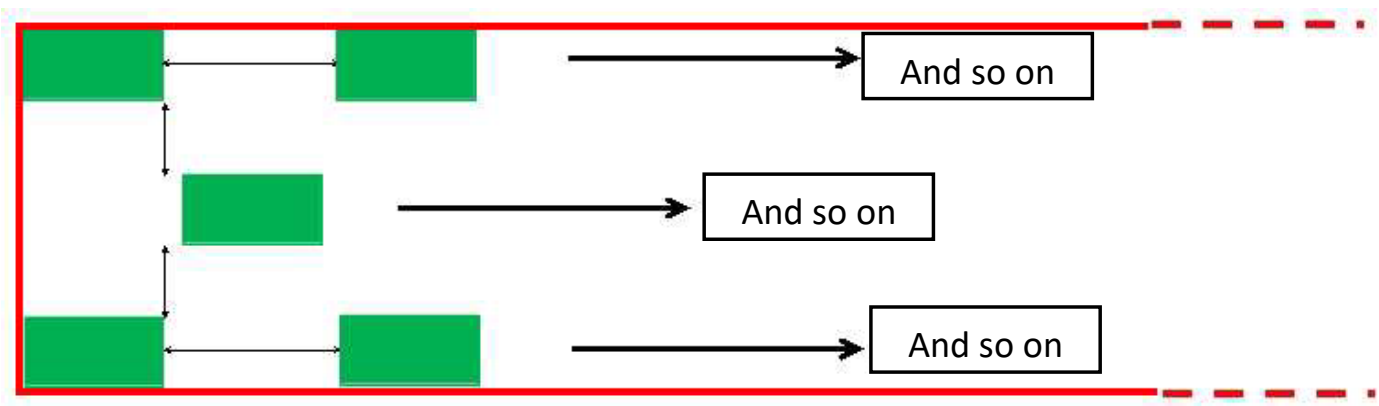

A group of mangroves

Figure 8 Cluster method

\subsection{Fish shelter data extraction}

The monitoring of fish shelters was carried out using a modified belt transect method referred to by Hill and Wilkinson (2004), which was also applied to standard reef fish studies conducted by the Indonesian Institute of Sciences. Fish playing in and around the fish shelter are recorded, photographed, counted and then identified by referring to Allen (1999) and Kuiter \& Tonozuka (2001). Each fish shelter is considered to represent an area of $2.5 \times 2.5 \mathrm{~m}^{2}$, so the total area is the result of multiplying the total number of fish shelters $\times 6.25 \mathrm{~m}^{2}$. Photographs were taken and recordings made of the natural recruitment of marine biota on the substrate, which sunk-a development due to the fish shelter module. Identification data were then analysed to obtain the value of the fish around the fish shelter: density, diversity index, uniformity and dominance. Fish availability and density were calculated using these formulae:

- Fish stocks $=$ individual number of fish in the area of the transect.

- Density = number of available fish/area of the transect.

Diversity is known by using the Shannon-Wiener index, which takes into account species richness and evenness (Magurran 1988). Diversity is calculated by using the formula:

$$
\mathrm{H}^{\prime}=\sum_{i=1}^{S} P i x \operatorname{Ln} P i
$$

where:

$$
\begin{aligned}
& \mathrm{H}^{\prime} \quad=\text { the diversity index. } \\
& \mathrm{Ln} \quad=\text { natural logarithm. } \\
& \mathrm{Pi} \quad=\text { the proportion of individuals in the ith species. } \\
& \mathrm{S} \quad=\text { the number of fish found in the fish shelter (community). }
\end{aligned}
$$

The proportion of individuals in the ith species is calculated by using the formula (Panhwar et al. 2016):

$$
\mathrm{Pi}^{\prime}=\frac{n i}{N}
$$

where:
$\mathrm{Pi}=$ the proportion of individuals in the ith species
ni $\quad=$ number of individuals of a species.
$\mathrm{N}=$ number of individuals of all species. 
Uniformity ( $\left.E^{\prime}\right)$ is calculated by using the formula:

$$
E^{\prime}=\frac{H^{\prime}}{H \prime \max }
$$

where:

$$
\begin{aligned}
& \mathrm{H}^{\prime} \quad=\text { the diversity index. } \\
& \mathrm{H}^{\prime} \text { max }=\text { the maximum uniformity index, using the formula: }
\end{aligned}
$$

$$
H^{\prime} \max =\frac{H^{\prime}}{\operatorname{Ln} S}
$$

where:

$\mathrm{S}=$ the total number of individuals of all types.

To find out the dominant type of fish, the Simpson Dominance Index is calculated, using:

$$
D=\sum_{i=1}^{s} P_{i}^{2}
$$

\begin{tabular}{|c|c|c|c|}
\hline $\begin{array}{l}\text { Domination range } \\
\text { (Krebs 1989) }\end{array}$ & $\begin{array}{l}\text { Diversity range } \\
\text { (Arifin et al. 2017) }\end{array}$ & $\begin{array}{l}\text { Uniformity range } \\
\text { (Krebs 1989) }\end{array}$ & $\begin{array}{l}\text { Range density/m² } \\
\text { (Djamali \& Darsono 2005) }\end{array}$ \\
\hline $0.01<D<0.30:$ Low & $H^{\prime}<1:$ Low & $\mathrm{E}<1.0$ : High & 1-5: Very rare \\
\hline $0.30<D<0.60:$ Medium & $1<H^{\prime}<3$ : Medium & $0.4<\mathrm{E}<0.6:$ Medium & 5-10: Rare \\
\hline \multirow[t]{3}{*}{$0.60<\mathrm{D}<1.00: \mathrm{High}$} & $\mathrm{H}^{\prime}>3:$ High & $E<0.4:$ Low & 10-20: Quite abundant \\
\hline & & & 20-50: Abundant \\
\hline & & & >50: Highly abundant \\
\hline
\end{tabular}

The criteria for reef fish are presented in Table 2.

Table 2 Coral fish criteria

\subsection{Coral transplant data collection}

Monitoring the results of coral transplantation is done by calculating the coral transplant success index value (IKb) and the life index of coral transplantation value (IKh). The formulae for calculating the indexes are as follows:

$$
\begin{gathered}
I K b=\frac{\text { Number of live transplant corals }}{\text { The total number of transplanted corals }(\text { live }+ \text { dead }+ \text { lost })} \\
I K h=\frac{\text { Number of live transplant corals }}{\text { The total number of live }+ \text { dead corals }}
\end{gathered}
$$

Each coral transplantation module is recorded and photographed to determine the number of corals that live, die and disappear. Additionally, photographing and recording were carried out for the natural recruitment of marine biota on the substrate, which sunk because of the development of the coral transplantation module. 


\subsection{Mangrove plantation data extraction}

The data for the mangrove plantation was taken at the beginning of March each year (Table 3).

Table 3 Mangrove plantation over a period of two years

\begin{tabular}{llll}
\hline No. & Location & $\begin{array}{l}\text { Year of } \\
\text { plantation }\end{array}$ & $\begin{array}{l}\text { Number } \\
\text { of plants }\end{array}$ \\
\hline 1 & Pelabuhan Sekumbang & 2017 & 1,000 \\
2 & Pantai Batu Kucing & 2017 & 1,000 \\
1 & Pantai Teluk Dalam & 2018 & 3,500 \\
2 & Pantai Kundur & 2018 & 7,500 \\
Total & & & 13,000 \\
\hline
\end{tabular}

\section{$3 \quad$ Results and discussion}

\section{1 $\quad$ Fish shelter monitoring results}

The data collected for each fish shelter includes data on the fish and marine biota in the sinking area. Additionally, after fish shelters were sunk, their condition was checked, especially with regard to any effects of wave surges and natural recruitment. The condition of the fish shelters on Panjang Island and in the Matras waters is generally good. There are only a few wire-shaped nets lining open fish shelters, and these are thought to have been caused by fishing nets or fishing rods. Fishermen used to catch fish at Matras waters; therefore, it is possible that nets or fishing rods have become entangled in the fish shelter during fishing activity. At Panjang Island, a fish shelter had been crushed by the wood dropped from the net by a fisherman while fishing. The two locations are still affected by sedimentation characterised by the presence of a layer of mud lining the fish shelter module. Figure 9 shows the condition of fish shelters.

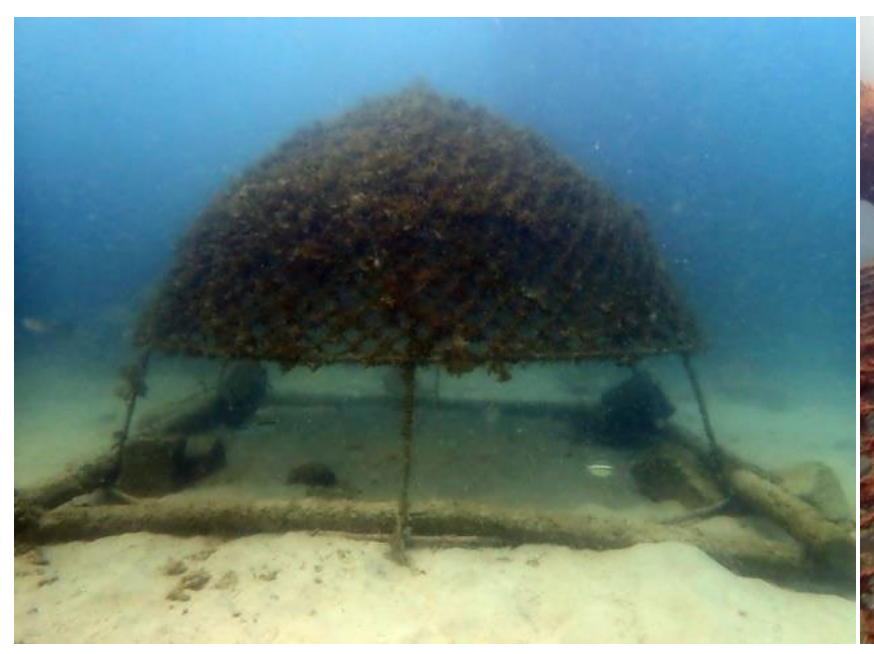

(a)

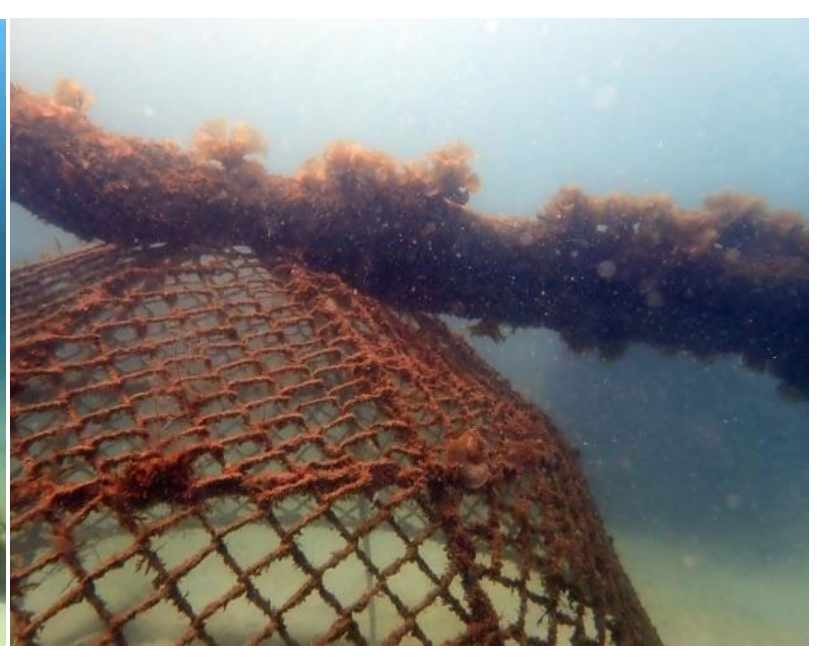

(b)

Figure 9 (a) Fish shelter with its semi-sphere shape covered in mud and microalgae; (b) Collapsed wooden beam drifting onto the fish shelter 
Data on the fish found in the location of the sinking of the Panjang Island fish shelter show as many as 29 species with 12 families (identification of fish species according to Allen [1999] and Kuiter \& Tonozuka ([2001]). In general, the diversity index value $\left(H^{\prime}\right)$ is 2.92 , which is within the criteria of 'moderate' because $1<H^{\prime}<3$. The dominance index value $(D)$ is 0.083 , which means it is included in the criteria of 'low' because $D<0.30$. This is the case because the composition of the fish is almost the same; no particular fish species dominates the fish population in terms of numbers. The species with the highest number of fish is Selaroides leptolepis or ciw in local name, which are of a small size and accounted for 47 from a total of 214 fish found. The uniformity index value (E) is 0.377 , which is within the criteria for 'low' because $E<0.4$, indicating that there is variety among the fish types. The low $E$ is because there are types of schooling fish (in groups), so their numbers are relatively large, as with the ciw. However, there are very few varieties because of the solitary life of other fish, such as (in local names) kerapu, buntal and katarap. The results of the data analysis are presented in Table 4.

Based on the data in Table 4, all of the fish types found are types of reef fish, which can be listed as three types of fish: target fish, indicator fish and major fish. According to Madduppa et al. (2012), target fish are a group or individual fish that provide economic value and food for fishermen, indicator fish are a group fish that indicate the level of health of a coral reef, and major fish are a group fish that play a general role in coral reef ecosystems, such as those from the family Pomacentridae and Caesionidae (Madduppa et al. 2012). The density of fish found was 0.856 fish per square metre. This means that only eight fish are found per $10 \mathrm{~m}^{2}$. This value is included in the very rare criteria (at less than five individuals per square metre) based on Djamali \& Darsono (2005), even though fish shelters are sunk not far from the coral reef ecosystem. This indicates that the fish shelter submerged beside the coral reef ecosystem is less effective. The small number of fish estimated is also due to Panjang Island's bustling maritime tourism, especially on weekends; local fishing activity (chart, fishing line and bubu); and ongoing turbidity from tin mining activities, especially community mines around the site.

Table 4 Results from study areas (continued next page)

\begin{tabular}{|c|c|c|c|c|c|c|c|c|c|}
\hline Fish species & Family & $\begin{array}{l}\text { Local } \\
\text { name }\end{array}$ & Number & $\mathbf{P i}$ & LN Pi & $\left(H^{\prime}\right)$ & (D) & (E) & Di \\
\hline $\begin{array}{l}\text { Pomacentrus } \\
\text { chrysurus }\end{array}$ & & $\begin{array}{l}\text { Betok } \\
\text { laut }\end{array}$ & 7 & 0.033 & 3.420 & 0.112 & 0.001 & 0.377 & 0.856 \\
\hline $\begin{array}{l}\text { Abudefduf } \\
\text { lorenzi }\end{array}$ & Pomacentridae & $\begin{array}{l}\text { Betok } \\
\text { laut }\end{array}$ & 12 & 0.056 & 2.881 & 0.162 & 0.003 & & \\
\hline $\begin{array}{l}\text { Neoglyphidodon } \\
\text { boning }\end{array}$ & & $\begin{array}{l}\text { Daun } \\
\text { bijur }\end{array}$ & 12 & 0.056 & 2.881 & 0.162 & 0.003 & & \\
\hline $\begin{array}{l}\text { Dischitodus } \\
\text { prosopotaenia }\end{array}$ & & $\begin{array}{l}\text { Betok } \\
\text { laut }\end{array}$ & 9 & 0.042 & 3.169 & 0.133 & 0.002 & & \\
\hline Lutjanus vitta & & $\begin{array}{l}\text { Seruit } \\
\text { ginggang }\end{array}$ & 21 & 0.098 & 2.321 & 0.228 & 0.010 & & \\
\hline $\begin{array}{l}\text { Lutjanus } \\
\text { boutton }\end{array}$ & Lutjanidae & $\begin{array}{l}\text { Tompel } \\
\text { karang }\end{array}$ & 5 & 0.023 & 3.757 & 0.088 & 0.001 & & \\
\hline $\begin{array}{l}\text { Lutjanus } \\
\text { carponotatus }\end{array}$ & & $\begin{array}{l}\text { Seruit } \\
\text { ginggang } \\
\text { Karang }\end{array}$ & 5 & 0.023 & 3.757 & 0.088 & 0.001 & & \\
\hline
\end{tabular}




\begin{tabular}{|c|c|c|c|c|c|c|c|c|c|}
\hline Fish species & Family & $\begin{array}{l}\text { Local } \\
\text { name }\end{array}$ & Number & $\mathbf{P i}$ & LN Pi & $\left(H^{\prime}\right)$ & (D) & (E) & Di \\
\hline $\begin{array}{l}\text { Lutjanus } \\
\text { biguttatus }\end{array}$ & & Seruit & 9 & 0.042 & 3.169 & 0.133 & 0.002 & & \\
\hline $\begin{array}{l}\text { Lutjanus } \\
\text { monostigma }\end{array}$ & & Kakap & 1 & 0.005 & 5.366 & 0.025 & 0.000 & & \\
\hline $\begin{array}{l}\text { Halichoeres } \\
\text { chloropterus }\end{array}$ & & Katarap & 7 & 0.033 & 3.420 & 0.112 & 0.001 & & \\
\hline $\begin{array}{l}\text { Halichoeres } \\
\text { javanicu } \\
\text { Chaerodon } \\
\text { anchorago }\end{array}$ & Labridae & $\begin{array}{l}\text { Katarap } \\
\text { atarap } \\
\text { merah }\end{array}$ & 2 & 0.009 & 4.673 & $\begin{array}{l}0.044 \\
0.060\end{array}$ & $\begin{array}{l}0.000 \\
0.000\end{array}$ & & \\
\hline $\begin{array}{l}\text { Chaerodon } \\
\text { schoenleinii }\end{array}$ & & $\begin{array}{l}\text { Katarap } \\
\text { ijau }\end{array}$ & 10 & 0.047 & 3.063 & 0.143 & 0.002 & & \\
\hline Scolopsis ciliate & & Kerisi & 8 & 0.037 & 3.287 & 0.123 & 0.001 & & \\
\hline $\begin{array}{l}\text { Scolopsis } \\
\text { margaritifer }\end{array}$ & & Kerisi & 7 & 0.033 & 3.420 & 0.112 & 0.001 & & \\
\hline $\begin{array}{l}\text { Pentapodus } \\
\text { setosus }\end{array}$ & & $\begin{array}{l}\text { Kerisi } \\
\text { bali }\end{array}$ & 13 & 0.061 & 2.801 & 0.170 & 0.004 & & \\
\hline $\begin{array}{l}\text { Pentapodus } \\
\text { bifasciatus }\end{array}$ & Nemipteridae & $\begin{array}{l}\text { Kerisi } \\
\text { bali }\end{array}$ & 2 & 0.009 & 4.673 & 0.044 & 0.000 & & \\
\hline $\begin{array}{l}\text { Scolopsis } \\
\text { trilineatus }\end{array}$ & & Kerisi & 1 & 0.005 & 5.366 & 0.025 & 0.000 & & \\
\hline Scolopsis affinis & & $\begin{array}{l}\text { Kerisi } \\
\text { bali }\end{array}$ & 4 & 0.019 & 3.980 & 0.074 & 0.000 & & \\
\hline Siganus virgatus & Siganidae & $\begin{array}{l}\text { Libem } \\
\text { karang }\end{array}$ & 6 & 0.028 & 3.574 & 0.100 & 0.001 & & \\
\hline $\begin{array}{l}\text { Selaroides } \\
\text { leptolepis }\end{array}$ & Carangidae & Ciw & 47 & 0.220 & 1.516 & 0.333 & 0.048 & & \\
\hline $\begin{array}{l}\text { Chelmon } \\
\text { rostatus }\end{array}$ & Chaetodontidae & $\begin{array}{l}\text { Kepe- } \\
\text { kepe }\end{array}$ & 4 & 0.019 & 3.980 & 0.074 & 0.000 & & \\
\hline $\begin{array}{l}\text { Upeneus } \\
\text { tragula }\end{array}$ & Mullidae & $\begin{array}{l}\text { Biji } \\
\text { nangka }\end{array}$ & 6 & 0.028 & 3.574 & 0.100 & 0.001 & & \\
\hline $\begin{array}{l}\text { Aluterus } \\
\text { scriptus } \\
\text { Acreichthys } \\
\text { tomentosus }\end{array}$ & Monacantidae & $\begin{array}{l}\text { Ayem- } \\
\text { ayem }\end{array}$ & 1 & 0.005 & 5.366 & $\begin{array}{l}0.025 \\
0.044\end{array}$ & 0.000 & & \\
\hline $\begin{array}{l}\text { Sargocentron } \\
\text { ittodai }\end{array}$ & Holocentridae & Samurai & 2 & 0.009 & 4.673 & 0.044 & 0.000 & & \\
\hline
\end{tabular}




\begin{tabular}{llllllllll}
\hline Fish species & Family & $\begin{array}{l}\text { Local } \\
\text { name }\end{array}$ & Number & $\mathbf{P i}$ & $\mathbf{L N ~ P i}$ & (H') & (D) & (E) & Di \\
\hline $\begin{array}{l}\text { Diagramma } \\
\text { pictum }\end{array}$ & Haemulidae & Seminyak & 3 & 0.014 & 4.267 & 0.060 & 0.000 & \\
$\begin{array}{l}\text { Plectorhinchus } \\
\text { chaetodonoides }\end{array}$ & & Seminyak & 2 & 0.009 & 4.673 & 0.044 & 0.000 & \\
$\begin{array}{l}\text { Taeniura lymma } \\
\text { Dasyatidae }\end{array}$ & Pari & 3 & 0.014 & 4.267 & 0.060 & 0.000 & \\
Total & & 214 & & & 2.920 & 0.093 & \\
\hline
\end{tabular}

Data on the fish found in the location of the sinking of the fish shelter in Matras waters show 16 types of 10 families (identification of fish species refers to Allen [1999] and Kuiter \& Tonozuka [2001]). In general, the diversity index value $\left(H^{\prime}\right)$ was 1.358 which is within the criteria for 'medium' because $1<H^{\prime}<2$. The dominance index value (D) of 0.422 is within the criteria for 'moderate' because $0.30<D<0.60$. This is because the fish population is dominated by Lutjanus madras, known locally as seruit, which numbered as many as 247 among the total 395 fish found, which means that the seruit alone account for $62.5 \%$ of the total fish found. The uniformity index value (E) of 0.158 is within the criteria for 'low' because $E<0.4$, which indicates a variety of fish types. The low $E$ is because there are several types of schooling fish (in groups) so that their numbers are relatively large, such as (in the local name) seruit ginggang, libem karang and tudung belangak. However, some types of fish have a low number because of their solitary life, such as kerapu, buntal, ketarap and seminyak. The results of the data analysis are presented in Table 5.

Table 5 Diversity index $\left(\mathrm{H}^{\prime}\right)$, uniformity index $(\mathrm{E})$, and dominance index $(\mathrm{D})$ for the type of fish at the sinking point in Matras waters (continued next page)

\begin{tabular}{|c|c|c|c|c|c|c|c|c|}
\hline Fish species & Family & $\begin{array}{l}\text { Local } \\
\text { name }\end{array}$ & Number & $\mathbf{P i}$ & LN Pi & $\left(H^{\prime}\right)$ & (D) & (E) \\
\hline $\begin{array}{l}\text { Cromileptis } \\
\text { altivelis }\end{array}$ & & Kerapu & 1 & 0.00253 & 5.97889 & 0.01514 & 0.00001 & 0.158 \\
\hline $\begin{array}{l}\text { Ephinephelus } \\
\text { amblycephalus }\end{array}$ & Serranidae & Kerapu & 1 & 0.00253 & 5.97889 & 0.01514 & 0.00001 & \\
\hline $\begin{array}{l}\text { Ephinephelus } \\
\text { corallicola }\end{array}$ & & Kerapu & 1 & 0.00253 & 5.97889 & 0.01514 & 0.00001 & \\
\hline $\begin{array}{l}\text { Plectorhinchus } \\
\text { flavomaculatus }\end{array}$ & Haemulidae & Seminyak & 3 & 0.00759 & 4.88027 & 0.03707 & 0.00006 & \\
\hline Platax teira & Ephippidae & $\begin{array}{l}\text { Tudung } \\
\text { belangak }\end{array}$ & 17 & 0.04304 & 3.14567 & 0.13538 & 0.00185 & \\
\hline $\begin{array}{l}\text { Siganus } \\
\text { guttatus }\end{array}$ & Siganidae & $\begin{array}{l}\text { Libem } \\
\text { karang }\end{array}$ & 22 & 0.05570 & 2.88784 & 0.16084 & 0.00310 & \\
\hline $\begin{array}{l}\text { Abalistes } \\
\text { stellatus }\end{array}$ & Balistidae & Jebung & 1 & 0.00253 & 5.97889 & 0.01514 & 0.00001 & \\
\hline Diodon hystrix & Tetraodontidae & $\begin{array}{l}\text { Buntal } \\
\text { besak }\end{array}$ & 1 & 0.00253 & 5.97889 & 0.01514 & 0.00001 & \\
\hline
\end{tabular}




\begin{tabular}{|c|c|c|c|c|c|c|c|}
\hline $\begin{array}{l}\text { Arothron } \\
\text { stellatus }\end{array}$ & & Buntal & 2 & 0.00506 & 5.28574 & 0.02676 & 0.00003 \\
\hline $\begin{array}{l}\text { Selaroides } \\
\text { leptolepis }\end{array}$ & Carangidae & Ciw & 55 & 0.13924 & 1.97155 & 0.27452 & 0.01939 \\
\hline $\begin{array}{l}\text { Nemipterus } \\
\text { furcosus }\end{array}$ & Nemipteridae & $\begin{array}{l}\text { Kerisi } \\
\text { merah }\end{array}$ & 3 & 0.00759 & 4.88027 & 0.03707 & 0.00006 \\
\hline Lutjanus vitta & & $\begin{array}{l}\text { Seruit } \\
\text { ginggang }\end{array}$ & 31 & 0.07848 & 2.54490 & 0.19973 & 0.00616 \\
\hline $\begin{array}{l}\text { Lutjanus } \\
\text { madras }\end{array}$ & & Seruit & 247 & 0.62532 & 0.46950 & 0.29358 & 0.39102 \\
\hline $\begin{array}{l}\text { Lutjanus } \\
\text { erythopterus }\end{array}$ & Lutjanidae & $\begin{array}{l}\text { Kakap } \\
\text { merah }\end{array}$ & 4 & 0.01013 & 4.59259 & 0.04651 & 0.00010 \\
\hline $\begin{array}{l}\text { Lutjanus } \\
\text { russelli }\end{array}$ & & $\begin{array}{l}\text { Tande- } \\
\text { tande }\end{array}$ & 5 & 0.01266 & 4.36945 & 0.05531 & 0.00016 \\
\hline $\begin{array}{l}\text { Choerodon } \\
\text { oligacanthus }\end{array}$ & Labridae & $\begin{array}{l}\text { Ketarap } \\
\text { ijau }\end{array}$ & 1 & 0.00253 & 5.97889 & 0.01514 & 0.00001 \\
\hline Total & & & 395 & & & 1.357 & 0.422 \\
\hline
\end{tabular}

Based on the data in Table 5, all of the fish types found are types of fish that can be consumed, except for Arothron stellatus or buntal, which are not commonly consumed by the people of Bangka. In some other regions and countries, however, these fish are consumed. If the sinking zone area is assumed to be $100 \mathrm{~m}^{2}$, the density of fish found was four fish per square metre. This density is within the criterion for very rare (at less than five fish per square metre) according to Djamali \& Darsono (2005). However, this criterion is actually used to assess coral reef ecosystems, which cannot be directly compared with submerged fish shelters because in coral reef ecosystems there are many types of fish, including major fish species, target fish and indicator fish (Fatimah et al. 2018. However, in the fish shelter area, according to the results of monitoring, the majority of species were target fish. The condition of the fish shelter is generally good and still intact. Moreover, the iron frames are plastered with barnacles, the algae macro is beginning to cover the wire mesh section. Additionally, gastropods (snails), sea rabbits (nudibranchs), sponges, sea cucumbers, soft coral, coral reefs, squid eggs and crustaceans (crabs) were found in the fish shelter module.

In general, the level of fish diversity in the fish shelters is higher in shallow and rocky areas (Panjang Island). However, the abundance of fish is lower when compared with fish shelters located in deeper water far from the coral reefs.

\subsection{Coral transplantation monitoring results}

The coral transplants were carried out along the edge of the coral reef at Panjang Island and Putri Island. The coral transplantation module is still intact; there is no major damage to the module. However, some broken substrate tiles need replacement. The tiles were probably broken by the anchor of a fishing boat or natural factors. Turbid water continues to affect the general condition of the coral transplants. Corals are very sensitive to turbid water conditions, especially coral that is to be transplanted. In both locations, many corals are covered with sediment, which causes most of the transplanted corals to die. The general results of the analysis of the coral transplants are presented in Table 6. 
Overall, the success index for coral transplants ranges from 41.6-64.8\%. This value is relatively high, especially when compared with the transplanted coral life index of $74.5 \%$ for Putri Island. The abundance of living coral transplants is assumed to be due to the shallower waters at Putri Island compared with the waters at Panjang Island. Due to the shallow waters, more sediment is washed away by the wave currents at Putri Island. However, the turbidity at Panjang Island is estimated to be higher than at Putri Island. However, based on previous research, the final results regarding coral life transplanted in the eastern waters of the new Bangka Island can be determined only after they have going through the western season in DecemberJanuary (summer). The coral transplantation module by recruitment has been plastered by natural corals, marine biota such as sponges, soft corals, algae, sea urchins and sea rabbits. In general, both locations are still affected by sedimentation and turbidity. The sinking of coral transplantation modules should be done in a location safe from these impacts in order to improve the success rate of living coral transplants and natural attachments even further.

Table 6 Results of the analysis of the success index (IKb) and life index (IKh) of coral transplants

\begin{tabular}{lllll}
\hline Location & Module number & Depth $(\mathrm{m})$ & IKb (\%) & IKh (\%) \\
\hline Putri Island & 100 & 3 & 64.809 & 74.545 \\
Panjang Island & 40 & 6 & 41.604 & 52.532 \\
\hline
\end{tabular}

\subsection{Local community participation}

The sinking of fish shelters and coral media was achieved by cooperating with a local group of fishermen. Through this cooperation, the local fishermen became more aware of the location of the fish shelter and coral media and avoided fishing in that location. Moreover, they warned tourists and other fishermen not to approach the area, since many of the signs erected by PT TIMAH Tbk to warn fishermen were stolen. Based on this experience, a factor that can influence the preservation of fish shelters and coral is the empowerment of the local fishermen.

\section{Conclusion}

The conclusions that follow are based on the results of this study. These conclusions may be beneficial as learning resources in marine rehabilitation activities in areas with marine mining such as at Bangka Island, the province of Bangka Belitung Islands.

- Based on the sinking of fish shelter modules in this study, we recommend that fish shelters be sunk in locations far from the island/coast and away from coral reefs. This is because proximity to coral reefs affects the fish population, especially in terms of the abundance level. Additionally, fish shelters should be sunk at a depth of more than 10 metres (the depth is measured from the average tide). Although the value of the fish diversity in Panjang Island locations close to natural coral reefs is higher, it appears that fish come to play for a short while only, and then return to their natural coral ecosystems.

- Sinking groups of 30 to 50 fish shelter modules at certain locations, such as at Matras waters, gives higher fish abundance compared with sinking locations adjacent to coral reefs or islands (e.g. Panjang Island).

- The sinking of coral transplants should be carried out in waters with a depth of two to three metres on average and low tides. The depth of the water influences the life of the coral. The deeper the water the more fatalities among the corals, and in open sea (exposed to higher currents) and deep 
sea (deeper than four metres), many are anchored by barnacles. In protected areas, especially in deep water, many of the corals become covered by sediment or mud.

- Determination of the types/forms of marine reclamation is better based on economic constraints (costs); legal, social and political conditions; and ecological factors. Ignoring the last point can lead to a high risk of failure (Edwards \& Gomez 2007). Impose no form or model that is not necessarily appropriate for application at the location to be reclaimed. Marine reclamation is applied as a form of physical restoration in marine restoration activities.

- Determination of the location for sinking should not only consider the impact of the mine. Ecological, social and regulatory conditions are other important factors that should be carefully considered. Coral transplants were observed to be less successful, and this is considered the case because anthropogenic influences in Bangka waters continue to occur. The location of coral transplants is still generally affected by negative anthropogenic effects. A more suitable location must be chosen.

Rules for marine reclamation in areas of tin mining activity have not been regulated in detail regarding the success of fish shelters and coral transplantation. Success criteria need to be determined clearly. However, the two sea reclamation activities in the three locations in this study show there is potential for success with fish shelters and coral transplantation if done in accordance with the following recommendations:

- In keeping with the results of this study, among others, the fish shelters and coral transplantations are appropriately implemented, located and supported, avoiding pollution and all significant anthropogenic disturbances.

- Coral reef rehabilitation programs are carried out in marine conservation areas (marine protected areas), which provide an opportunity for corals to recover because such areas can be more effectively protected from fishing activities that are not environmentally friendly.

- Local fishermen are empowered to participate in the group activity of preserving the fish shelter and coral. Despite the fact that in several areas the shelters were damaged by fishing equipment, local fishermen were avoiding fishing in the areas where fish shelters were located and informing other fishermen and tourists to do the same, thus raising awareness of the existence of fish shelters and coral transplants.

\section{Acknowledgement}

The authors wish to thank those who have contributed to our research. Also, special thanks and appreciation go to Mr Sri Raharjo, Director of Technical and Environmental Mineral and Coal, Ministry of Energy and Mineral Resources, and Mr Alwin Albar, Director of Operations and Production, PT TIMAH Tbk for their valuable support for this research.

\section{References}

Adger, WN, Kelly, PM \& Tri, NH 1997, 'Valuing the products and services of mangrove restoration', The Commonwealth Forestry Review, vol. 76, no. 3, pp. 198-202.

Adibrata, S 2013, 'Evaluasi kondisi terumbu karang di Pulau Ketawai Kabupaten Bangka Tengah', Jurnal Kelautan, vol. 6, no. 1, pp. 1928, http://dx.doi: 10.21107/jk.v6i1.829

Allen, G 1999, 'Altrichthys, a new genus of damselfish (Pomacentridae) from Philippine seas with description of a new species', Revue Française d'Aquariologie, vol. 26, no. 1-2, pp. 23-28.

Arifin, F, Dirgayusa, IGNP \& Faiqoh, E 2017, 'Struktur komunitas ikan dan tutupan karang di area biorock Desa Pemuteran, Buleleng, Bali', Journal of Marine and Aquatic Sciences, vol. 3 no. 1, pp. 59-69, http://dx.doi: 10.24843/jmas.2017.v3.i01.59-69

Bak, RPM 1978, 'Lethal and sublethal effects of dredging on reef corals', Marine Pollution Bulletin, vol. 9, no. 1, pp. 14-16, http://dx.doi: 10.1016/0025-326X(78)90275-8 
da Silva Borges Barbosa, V, de Lima, HM, Laudares, S \& Fonseca, BM 2019, 'Mine closure in Ouro Preto: the remnants of the 18th century gold rush and the tourism as an economic opportunity', REM - International Engineering Journal, vol. 72, pp. 39-46.

Bowden-Kerby, A 2003, 'Coral transplantation and restocking to accelerate the recovery of coral reef habitats and fisheries resources within no-take marine protected areas: hands-on approaches to support community-based coral reef management', paper presented at the Second International Tropical Marine Ecosystems Management Symposium, Manilla, 24-27 March.

Chabanet, P, Adjeroud, M, Andréfouët, S, Bozec, Y-M, Ferraris, J, Garcia-Charton, J-A \& Schrimm, M 2005, 'Human-induced physical disturbances and their indicators on coral reef habitats: a multi-scale approach', Aquatic Living Resources, vol. 18, no. 3, pp. 215-230, http://dx.doi: 10.1051/alr:2005028

Chansang, H 1988, 'Coastal tin mining and marine pollution in Thailand', Ambio, vol. 17, no. 3, pp. 223-228.

Charlier, RH 2002, Impact on the coastal environment of marine aggregates mining', International Journal of Environmental Studies, vol. 59, no. 3, pp. 297-322, http://dx.doi: 10.1080/00207230211304

Clark, S \& Edwards, AJ 1999, 'An evaluation of artificial reef structures as tools for marine habitat rehabilitation in the Maldives', Aquatic Conservation: Marine and Freshwater Ecosystems, vol. 9, no. 1, pp. 5-21, http://dx.doi:10.1002/(SICI)10990755(199901/02)9:1<5::AID-AQC330>3.0.CO;2-U

Djamali, A \& Darsono, P 2005, Petunjuk teknis lapangan untuk penelitian ikan karang di ekosistem terumbu karang. Materi Kursus. Pusat Dokumentasi dan Informasi IImiah-LIPI. Jakarta.

Edwards, AJ \& Gomez, ED 2007, Konsep dan panduan restorasi terumbu: membuat pilihan bijak di antara ketidakpastian: Yayasan Terumbu Karang Indonesia.

Ellis, JI, Clark, MR, Rouse, HL \& Lamarche, G 2017, 'Environmental management frameworks for offshore mining: the New Zealand approach', Marine Policy, vol. 84, pp. 178-192, http://dx.doi: 10.1016/j.marpol.2017.07.004

Ellison, JC 1993, 'Mangrove retreat with rising sea-level, Bermuda', Estuarine, Coastal and Shelf Science, vol. 37, no. 1, pp. 75-87, http://dx.doi: 10.1006/ecss.1993.1042

Fatimah, S, Putra, TWLP, Kondang, P., Suratman, Gamelia, L., Syahputra, H ... Ambariyanto, A 2018, 'Diversity of coral fish at Saebus Island, East Java, Indonesia', E3S Web of Conferences, vol. 31, no. 08021, pp. 1-5, http://dx.doi:10.1051/e3sconf/2018310802

Finstad, A, Einum, S, Forseth, T \& Ugedal, 0 2007, 'Shelter availability affects behaviour, size-dependent and mean growth of juvenile Atlantic salmon', Freshwater Biology, vol. 52, no. 9, pp. 1710-1718.

Gilman, EL, Ellison, J, Jungblut, V, Van Hanneke, H, Wilson, L, Areki, F, . . Yuknavage, K 2006, 'Adapting to Pacific Island mangrove responses to sea level rise and climate change', Climate Research, vol. 32, no. 3, pp. 161-176.

Guzmán, HM 1991, 'Restoration of coral reefs in Pacific Costa Rica', Conservation Biology, vol. 5, no. 2, pp. 189-194, http://dx.doi:10.1111/j.1523-1739.1991.tb00123.x

Hill, J \& Wilkinson, C 2004, Methods for Ecological Monitoring of Coral Reefs, Version 1, Australian Institute of Marine Science, Townsville.

Jaap, WC 2000, 'Coral reef restoration', Ecological Engineering, vol. 15, no. 3, pp. 345-364, http://dx.doi: 10.1016/S0925$85740000085-9$

Krebs, CJ 1989, Ecological Methodology, Harper \& Row, New York.

Kuiter, RH \& Tonozuka, T 2001, Pictorial Guide to Indonesian Reef Fishes, Zoonetics, Seaford.

Limpitlaw, D \& Briel, A 2014, 'Post-mining land use opportunities in developing countries: a review', Journal of the Southern African Institute of Mining and Metallurgy, vol. 114, pp. 899-903.

Madduppa, HH, Farhan, AR \& Suhendra, D 2012, 'Fish biodiversity in coral reefs and lagoon at the Maratua Island, East Kalimantan', Biodiversitas, Journal of Biological Diversity, vol. 13, no. 3, pp. 145-150, http://dx.doi: 10.13057/biodiv/d130308

Magurran, AE 1988, Ecological Diversity and its Measurement, Princeton University Press, Princeton.

Nurtjahya, E, Franklin, J, Umroh \& Agustina, F 2017, The Impact of tin mining in Bangka Belitung and its reclamation studies. MATEC Web of Conferences, vol. 101, no. 04010, http://dx.doi: 10.1051/matecconf/201710104010

Panhwar, SK, Farooq, N, Qamar, N \& Awan, KP 2016, 'Increasing trends in capture of fish juveniles and sub-adults: a red signal for fishery resources', Indian Journal of Geo-Marine Sciences, vol. 45, no. 6, pp. 784-788.

Saenger, P \& Siddiqi, N 1993, 'Land from the sea: the mangrove afforestation program of Bangladesh', Ocean \& Coastal Management, vol. 20, no. 1, pp. 23-39.

Saragih, HP 2018, 'Harga timah anjlok, laba TINS tergerus 15\%', CNBC Indonesia, viewed 28 February 2019 https://www.cnbcindonesia.com/market/20181129161417-17-44299/harga-timah-anjlok-laba-tins-tergerus-15

Senecal, P, Goldsmith, B, Conover, S, Sadler, B \& Brown, K 1999, Principles of Environmental Impact Assessment Best Practice, International Association for Impact Assessment, Fargo.

Shaish, L, Levy, G, Gomez, E \& Rinkevich, B 2008, 'Fixed and suspended coral nurseries in the Philippines: establishing the first step in the "gardening concept" of reef restoration', Journal of Experimental Marine Biology and Ecology, vol. 358, no. 1, pp. 86-97, http://dx.doi: 10.1016/j.jembe.2008.01.024

Shiau, Y-J, Lee, S-C, Chen, T-H, Tian, G \& Chiu, C-Y 2017, 'Water salinity effects on growth and nitrogen assimilation rate of mangrove (Kandelia candel) seedlings', Aquatic Botany, vol. 137, pp. 50-55, http://dx.doi: 10.1016/j.aquabot.2016.11.008

Siburian, R \& Haba, J 2016, Konservasi mangrove dan kesejahteraan masyarakat, Yayasan Pustaka Obor Indonesia, Jakarta.

Siringoringo, RM \& Hadi, TA 2013, Kondisi dan distribusi Karang Batu (Scleractinia corals) di Perairan Bangka. Jurnal IImu dan Teknologi Kelautan Tropis, vol. 5, no. 2, pp. 273-285. 
Soni, A, Mishra, B \& Singh, S 2014, 'Pit lakes as an end use of mining: a review', Journal of Mining and Environment, vol. 5, no. 2, pp. 99-111.

Soong, K \& Chen, T-a 2003, 'Coral transplantation: regeneration and growth of Acropora fragments in a nursery', Restoration Ecology, vol. 11, no. 1, pp. 62-71, http://dx.doi: 10.1046/j.1526-100X.2003.00100.x

Steele, MA 1999, 'Effects of shelter and predators on reef fishes', Journal of Experimental Marine Biology and Ecology, vol. 233, no. 1, pp. 65-79, http://dx.doi: 10.1016/S0022-0981(98)00127-0

Wakushima, S, Kuraishi, S \& Sakurai, N 1994, 'Soil salinity and pH in Japanese mangrove forests and growth of cultivated mangrove plants in different soil conditions', Journal of Plant Research, vol. 107, no. 1, pp. 39-46, http://dx.doi: 10.1007/bf02344528

Wang, J, Zhao, F, Yang, J \& Li, X 2017, 'Mining site reclamation planning based on land suitability analysis and ecosystem services evaluation: a case study in Liaoning Province, China', Sustainability, vol. 9, no. 6, p. 890.

Zipper, CE, Burger, JA, Skousen, JG, Angel, PN, Barton, CD, Davis, V \& Franklin, JA 2011, Restoring forests and associated ecosystem services on Appalachian coal surface mines', Environmental Management, vol.47, no. 5, pp. 751-765, http://dx.doi: 10.1007/s00267-011-9670-z 